Teknomekanik

Vol.3, No.1, May 2020, pp. $1 \sim 8$

e-ISSN: $2621-8720$ p-ISSN: 2621-9980

\title{
Porosity Defect Analysis in ST 37 Steel Welding Joints Using the Dye Penetrant Method
}

\author{
Alan Wari ${ }^{1 *}$, Hendri Nurdin ${ }^{2}$ and Kyaw Zay $\mathbf{Y a}^{3}$ \\ ${ }^{12}$ Jurusan Teknik Mesin, Universitas Negeri Padang, Indonesia \\ ${ }^{3}$ Mechanical Engineering Department, Thanlyin Technological University, Myanmar
}

Article Info
Article history:
Received January $09^{\text {th }}, 2020$
Revised March $10^{\text {th }}, 2020$
Accepted April $25^{\text {th }}, 2020$

\section{Keywords:}

Dye Penetrant

SMAW

Porosity

\begin{abstract}
Procedures in the welding are not easy, but all welding simply must have extensive knowledge under the definition of welding. This welding is a permanent connection technique, when the welding process takes place the results do not always meet the quality standards that have been determined. The cause of welding results that do not meet the quality standards is in the form of dirt on the material welding and so forth. The purpose of this study is that the specimen specimens are accepted based on the acceptance criteria standard of the] welding Institute (TWI). This research uses st 37 steel using SMAW welding electrodes LB $52 U$ (E 7016) diameter $2.6 \mathrm{~mm}$ for root, and $L B 52 U$ (E 7016) diameter 3.2 for fillers with $1 G$ seam position welding $V$. Testing of welding results are carried out with a non-destructive test dye penetrant method whose inspection results are determined based on the standard. The results of this test study discontinuity in the form of porosity on the surface of the welding results in specimen 1, namely material contaminated by dirt there are porosity defects scattered with a length of $6 \mathrm{~mm}$ and porosity of $10 \mathrm{~mm}$ so that based on TWI standards both test specimens are declared rejected, and in specimen 2 that is material that is not contaminated with dirt there are porosity defects of $2 \mathrm{~mm}$ and $2.5 \mathrm{~mm}$ so based on the standards of the two test specimens declared accepted. The results of welding defects that are rejected can still be repaired by linking the defects that occur and can be welding again.
\end{abstract}

\section{Corresponding Author:}

Alan Wari,

Jurusan Teknik Mesin, Fakultas Teknik, Universitas Negeri Padang

Jln. Prof. Dr. Hamka Air Tawar, Padang (25131), Sumatera Barat, Indonesia

Email: alanwari822@gmail.com

\section{INTRODUCTION}

The development of production technology that utilizes metal raw materials is inseparable with welding technology. Welding is also a work that is often used in the connection of plates, welding in oil pipes, shipping, construction of bridges, tanks, construction of skyscrapers, railroad tracks, and others. All that does not escape from a welding process. The many welding processes that are carried out often occur in metal welding the results do not always meet the standards and also the number of defects that occur in the welding process. The welding process can cause physical changes in the weld metal so that it can affect the quality of the weld which is caused by improper welding methods. The welding procedure has a standard, but the standard is not a guarantee of quality [1] The welding process can be divided into two categories, namely consumable electrodes and non-consumable electrodes. Of the many welding processes, the results do not always meet the standards. Failures that can occur in the welding process include undercut, over spatter, hot crack, cold cracking, and porosity.

Porosity (porosity) is a welding defect that occurs in the form of small holes in the metal. There are four types of porosity welding defects which are porosity, scattered porosity, longitudinal porosity, cluster porosity. Porous or porosity caused by a humid or wet welding environment, dirty smudges, wind blowing on the surface of the weld, galvanized coating, wrong type of current, wrong type of polarity, amperage capping is too large. As a result, weakens the connection, looks bad, initiates surface rust [2]. Failure in the welding 
process in the form of welding defects that occur, so it is necessary to inspect the welding results to comply with operating and safety standards. One of the methods to inspect the welding results used is the NonDestructive Test (NDT). Non-Destructive Testing (NDT) is defined as a physical evaluation of a solid object being tested. NDT is used primarily in the industrial world to detect defects, cracks, and cavities in materials used in various structures with different types of material [3]

Non-destructive Test (NDT) has many methods for the testing process, among these methods have advantages and disadvantages of each, no one is the best because of the many methods that have advantages that are not owned by other methods. The following are some methods including; visual test method, ultrasonic inspection, radiography inspection, eddy current, magnetic particle inspection, proof test, leak test, and dye penetrant method [4].The dye penetrant or liquid penetrant test method is the simplest NDT method. This method is used to find defects in exposed surfaces in solid components, both metal and non-metal, such as ceramics and plastic fibers. Before testing, the defects that occur are required inspection, visual inspection is done by looking directly at the welded test object. These are the terms and conditions that must be carried out in the welding connection inspection. Each welded joint test object must be visually inspected first and meet the requirements [5] There are two types of dye penetrant methods, namely the visible penetrant and fluorescent penetrant methods. visible penetrant is a penetration spray method using red liquid and can be seen directly. This method can be used in general (under white light) without using ultraviolet light. Visible penetrant also requires a liquid remover and developer. Fluorescent penetrant is a penetration method that uses ultraviolet light or can also use the light on a cellphone flashlight and so on, this method relies on a dark room [6]. Test using dye penetrant is suitable for testing cracks and porosity that occur on the surface. This liquid dye penetrant method is simple, but the dye penetrant method has the advantage of speed and accuracy in detecting defects that occur on the surface. This method can be used to find defects that occur on exposed surfaces such as solid, metal, and non-metal components, ceramics, and plastic fibers. With this method, an indication of surface defects that occur can be seen more clearly [7].

\section{METHOD}

In this study using Steel 37 steel material plate profile with $8 \mathrm{~mm}$ plate thickness, $300 \mathrm{~mm}$ plate length, and $100 \mathrm{~mm}$ plate width. The welding process is carried out by a type of electric arc welding (SMAW). In welding using seam type $\mathrm{V}$ with $1 \mathrm{G}$ welding position under the hand.

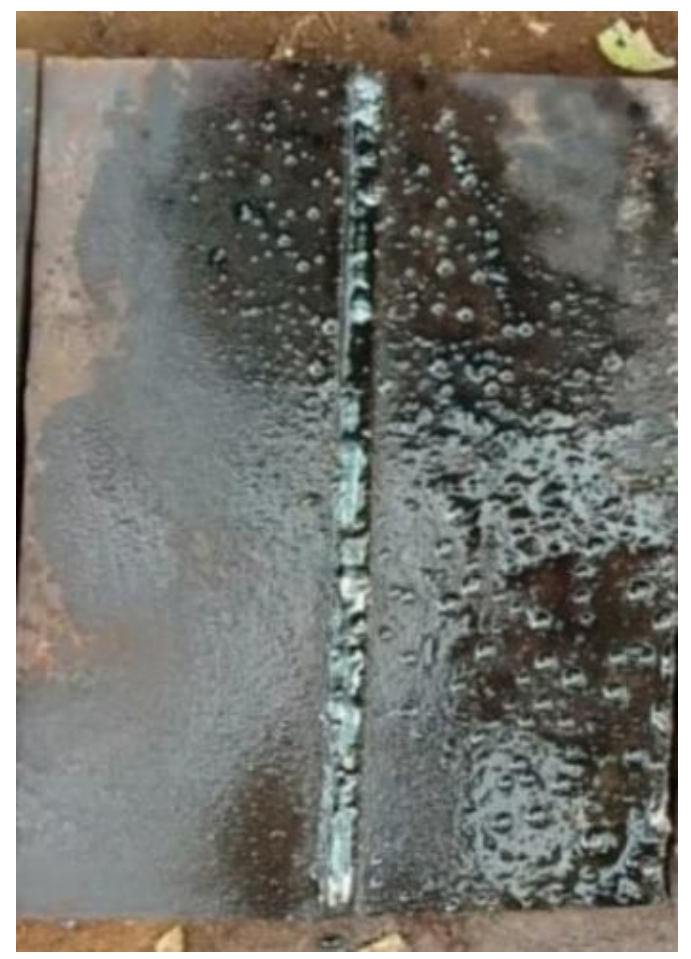

Figure 1 : Welding Results of 1G Contaminated with Dirt 


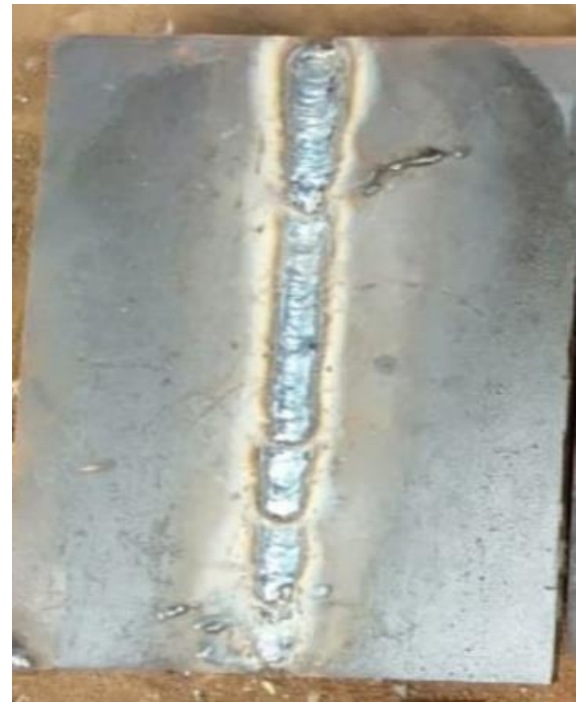

Figure 2: Welding Results of 1G Contaminated with Dirt

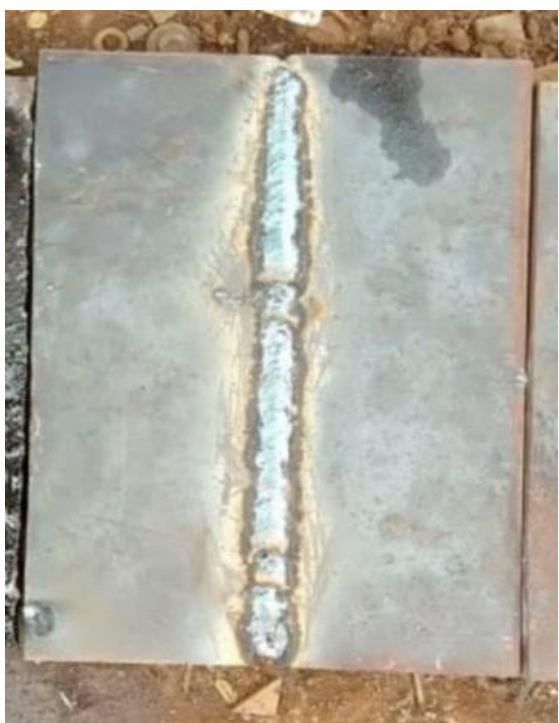

Figure 3 : Welding Results of 1G Contaminated with Dirt

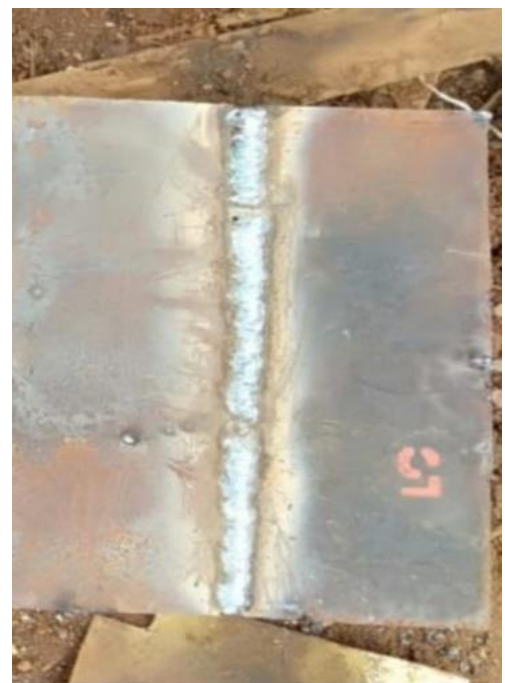

Figure 4 : Welding Results of 1G Contaminated with Dirt 
The electrodes used were E-7016 (LB 52U) with a diameter of $2.6 \mathrm{~mm}$ and a diameter of $3.2 \mathrm{~mm}$ for fillers and caping.

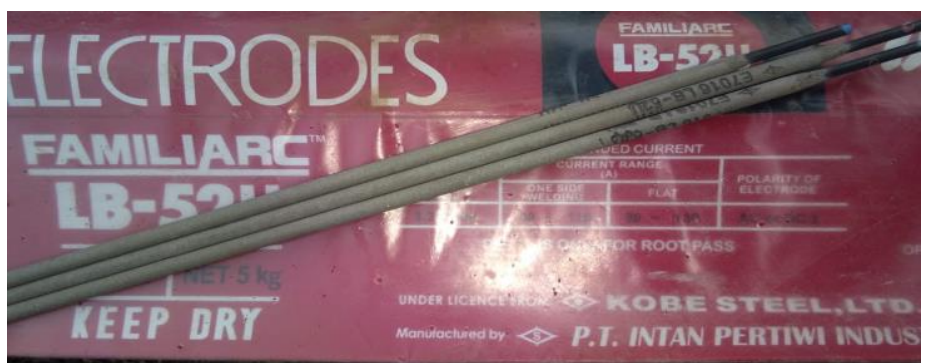

Figure 5 : Electrodes

NDT testing using the spot penetrant dye penetrant method uses a fluorescent type magnaflux with SKC-S Cleaner, SKL-SP2 Penetrant, and SKD-S2 Developer.

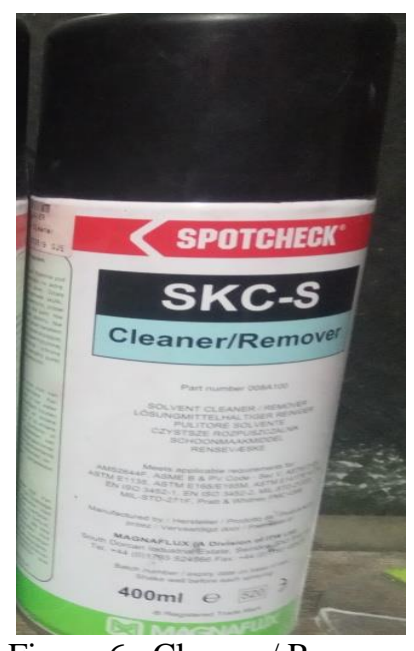

Figure 6 : Cleaner / Remover

Cleaner functions as a cleaning process on the object to be tested, this process is a cleaner remover sprayed on the test object so that there are no indications of dirt such as oil, rust, or other impurities.

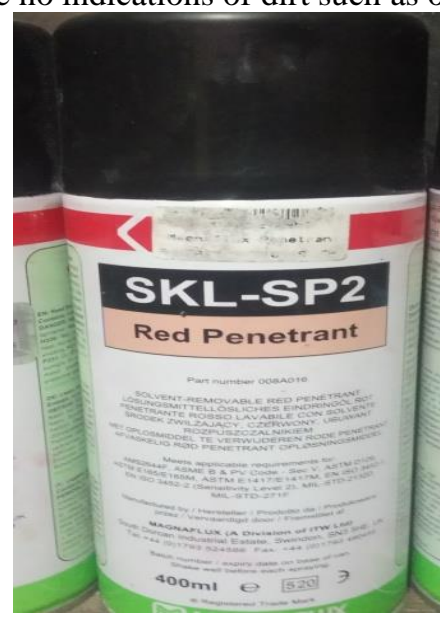

Figure 7 : Red Penetrant

This red penetrant functions as a liquid that will seep into the defective pores of the material that occurs for this red penetrant fluid takes 5 to 10 minutes to soak properly into the pores of the defective pores.

Journal homepage: http://teknomekanik.ppj.unp.ac.id

DOI: https://doi.org/10.24036/tm.v3i1.5272 


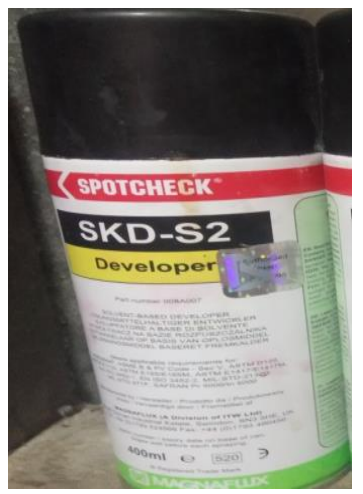

Figure 8 : Developer

The developer is a liquid that will release red penetrant fluid that has seeped into the pores of the defect that occurs or the developer fluid serves as the development fluid to see the indication of defects that occur clearly.

The NDT dye penetrant testing process can be carried out as follows:

a. Prepare all the necessary equipment.

b. Clean the surface of the material by using a steel brush to remove dirt on the surface of the welding material.

c. Clean the surface of the welding by using a cleaner/remover so that oil and other impurities are gone.

d. Wait until the cleaner fluid dries, spray evenly the red penetrant liquid on the welding surface.

e. Leave for 10 minutes until the penetrant liquid seeps into the gap that occurs defects.

f. Remove the excess red penetrant fluid using a cleaner that is sprayed on the cucumber.

g. The removal process is done in one direction.

h. Spray the developer liquid to the surface of the welding material until it is evenly distributed.

i. Wait for 10 minutes for the developer fluid to develop an indication of a defect that has occurred.

j. Inspect the welding results after spraying the developer.

k. See the indication of defects that exist and make measurements on the indication of defects obtained.

1. Clean and store back the equipment used in its original position.

\section{RESULTS}

NDT method is a test on an object without damage so that it can detect welding defects with a particular procedure. From the results of tests carried out, there are porosity defects in the welding connection. As shown in Figure 1 where the results of inspection defects that occur using the dye penetrant test method. Figure 1 shows the porosity defects that occur can be seen from the widening red penetrant fluid.

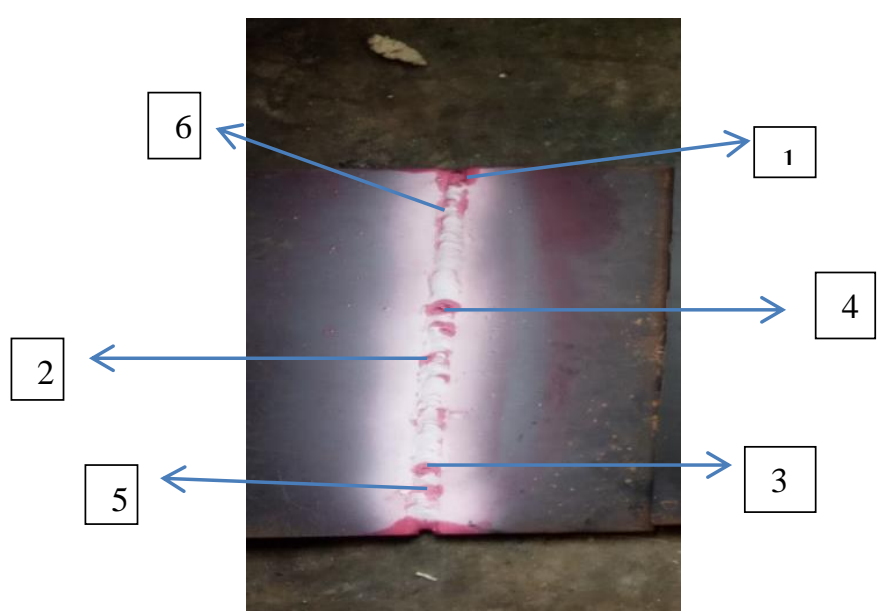

Figure 9 : Welding Inspection Results Using Dye Penetrant. 


\begin{tabular}{cccc}
\multicolumn{4}{c}{ Table $1:$ Total Amount of Results of Discontinuity } \\
\hline No & Porosity size $(\mathrm{mm})$ & Indication & Remarks \\
\hline 1 & 8 & Cluster Porosity & Rejected \\
2 & 5 & Porosity & Rejected \\
3 & 2 & Porosity & Accepted \\
4 & 3 & Porosity & Accepted \\
5 & 5 & Porosity & Rejected \\
6 & 2 & Porosity & Accepted
\end{tabular}

The results of the non-destructive test dye penetrant against welding SMAW Kampung V contaminated with paint, oil, oil, etc., can be seen in figure (9) namely the defects that occur in the form of porosity, the amount of porosity that occurs in figure 6 defects that occur in the form porosity. The first defect occurs porosity cluster with a size of $8 \mathrm{~mm}$ defect, the defect result is declared rejected because it exceeds the predetermined standard, the second defect that occurs porosity with a porosity defect size $5 \mathrm{~mm}$, the result of this defect can be declared rejected because it exceeds the specified standard limits. Defect number 3 is still a porosity defect with a defect size of $2 \mathrm{~mm}$, the defect that occurred is still declared acceptable because it is still within the standard limits. Furthermore, defects that occur in the designated image number 4 in the form of porosity defects and number 5 defects that occur $5 \mathrm{~mm}$ defects that occur are porosity, for size defects that occur in number 4 declared accepted and 5 declared rejected, then the defects that occur in with the appointment number 6 defects that occur are porosity with a size of $2 \mathrm{~mm}$ defects, these defects are also still in the standard limits and are declared accepted.

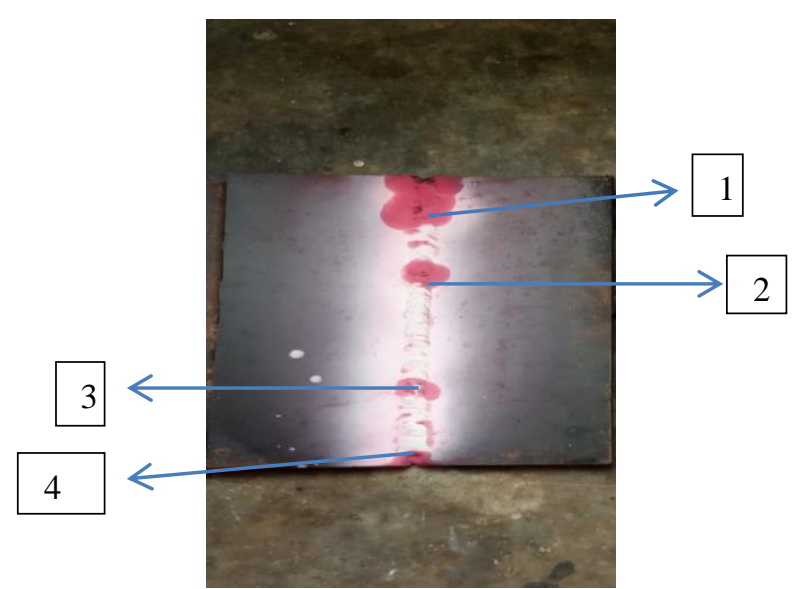

Figure 10 : Welding Inspection Results Using Dye Penetrant.

Table 2: Total Amount of Results of Discontinuity Material Indications

\begin{tabular}{cccc}
\hline No & Porosity size $(\mathrm{mm})$ & Indication & Remarks \\
\hline 1 & 12 & Wormholes Porosity & Rejected \\
2 & 6 & Cluster Porosity & Rejected \\
3 & 2 & Porosity & Accepted \\
4 & 2.5 & Porosity & Accepted \\
\hline
\end{tabular}

Figure (10) is also the result of welding SMAW Kampung V that is contaminated with dirt and so on, carried out by dye penetrant testing, can be seen directly, namely the development of red penetrant fluid, in that development is a porosity defect that occurs which amounts to 4 porosity defects. The first is a wormholes porosity defect with a $12 \mathrm{~mm}$ defect size that occurs when this defect is declared rejected. The second is the cluster porosity defect with a defect size of $6 \mathrm{~mm}$ and this defect is declared rejected. The third is the porosity defect with a defect size of $2 \mathrm{~mm}$. This defect is declared accepted, and the last defect has occurred porosity with a defect size of $2.5 \mathrm{~mm}$, this defect is still declared accepted. Based on the table above the results of the welding carried out there are defects that occur. The defects that occur according to the standards of The Welding Institute have been rejected because the welding results exceed the predetermined standard limits.

Journal homepage: http://teknomekanik.ppj.unp.ac.id

DOI: https://doi.org/10.24036/tm.v3i1.5272 


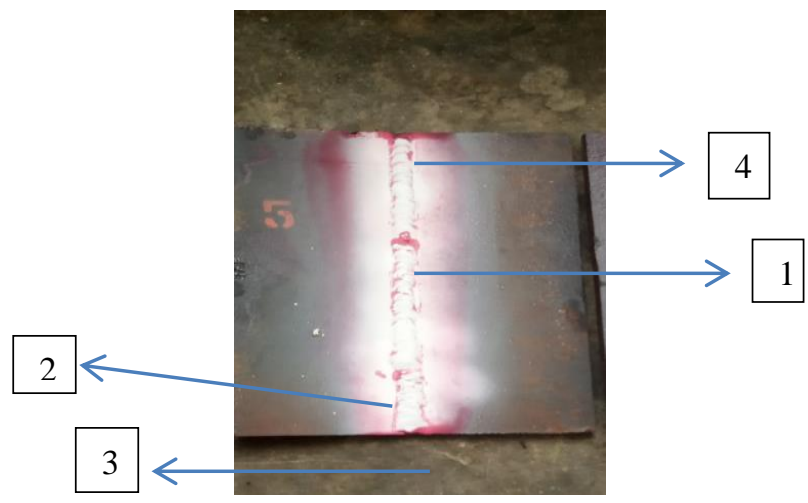

Figure 11 : Welding Inspection Results Using Dye Penetrant.

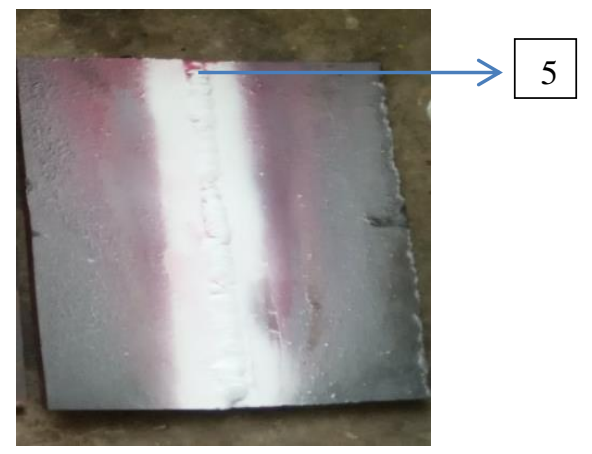

Figure 12 : Welding Inspection Results Using Dye Penetrant.

Table 3: Total Number of Indications of Discontinuity Material 11 and 12 that are not Contaminated with Dirt.

\begin{tabular}{cccc}
\hline No & Porosity size $(\mathrm{mm})$ & Indication & Remarks \\
\hline 1 & & & \\
2 & 3 & Porosity & Accepted \\
3 & 3 & Porosity & Accepted \\
4 & 2 & Porosity & Accepted \\
5 & 1 & Porosity & Accepted \\
\hline
\end{tabular}

Figures (11 and 12) are also the result of welding seam SMAW V that is not contaminated with dirt and so on, the results of welding are done by testing dye penetrant, can be seen directly, namely the development of red penetrant fluid, the development of red penetrant fluid is a defect that happened. Porosity defects that occur in the appointment of numbers 1 and 2, namely porosity defects with a size of 3mm defects, defects that occur are declared accepted because they are still within the standard limits. Furthermore, the defects that occur in tables number 3 to number 5 are still porosity which is the size of the porosity defects that occur $2 \mathrm{~mm}, 1 \mathrm{~mm}$, and $2.5 \mathrm{~mm}$, the defects that occur are still declared acceptable because they are still within the standard limits. From table 2 above according to the TWI standard dye penetrant testing method that there are indications of defects that occur, based on the standard used defects that occur are still within the criteria accepted even though there are indications of defects that occur.

\section{CONCLUSION}

Based on the data that has been obtained, several conclusions can be drawn. After testing with the dye penetrant method, it can be seen directly the comparison between the welding results contaminated with paint, oil, or other impurities which has a very negative impact on the welding results with the occurrence of many defects, especially porosity defects. On the results of specimen testing in figure 1, there is porosity that occurs beyond the standard that has been set and declared rejected, while in specimen testing of image 2 there are also porosity defects that occur, but the defects that occur are still within the standard limits and the 
welding results are acceptable. For the welding defects, results that are rejected can still be repaired by linking the defects that occur and can be welding again.

\section{REFERENCES}

[1] Irzal and Nurdin, H. Analisis Kekuatan Tarik Sambungan Las Pada pipa Baja Karbon Menggunakan Elektroda E 7018 Dengan Posisi Pengelasan 5G. Prosiding Konvensi Nasional APTEKINDO VII dan Teтu Karya XVIII FPTK/FT-JPTK Se-Indonesia, pp. 374-579. 2015.

[2] Anggraini, D. A. and Putra, N.P. Implementasi Six Sigma Untuk Mengurangi Cacat Las Jenis Porosity Pada Pengelasan Pipa Steam Di Project NND Area 12 PT. CPI Duri Riau 12. Jurnal Teknik Industri Universitas Bung Hatta, Vol. 1, No. 1. 2012.

[3] Nugroho, A. And Setiawan, E. Pengaruh Variasi kekuatan Arus Pengelasan Terhadap Kekuatan dan kekerasan Sambungan Las Plate Carbon Steel ASTM 36. Jurnal Rekayasa Sistem Industri. Volume 3. No. 1., pp. 134-142. 2018.

[4] Endramawan, T. and Sifa, A., 2017. Aplikasi Standar AWS Untuk Menentukan Acceptance Criteria Pada Pengelasan Smaw Menggunakan Non-Destruktive Test-Ultrasonic Test. Turbo, Vol. 6, No. 1, pp. 110-116. 2017.

[5] Soebagyo, H., Kusuma, G. C. and Hernadi. Pemeriksaan Sambungan Las Aluminium Pada Struktur Kereta Api Ringan Dengan Metode Non-Destructive Test. Jurnal ASSIMETRIK: Jurnal Ilmiah Rekayasa \& Inovasi. Vol. 1, No. 1, pp. 58-64. 2019.

[6] Endramawan, T., Haris, E., Dionisius, F. and Prinka, Y. Aplikasi Non - Destructive Test Penetrant Testing (NDT-PT) Untuk Analisis Hasil Pengelasan Smaw 3G Butt Joint. Jurnal Teknologi Terapan, Vol. 3, No. 2, pp. 44-48. 2017. 